\title{
Sudden visual loss: intraocular lens subluxation
}

\author{
Huw Oliphant, Christopher Holmes, Ali Hassan, Chee Kon
}

Department of Ophthalmology, Worthing Hospital, Worthing, West Sussex, UK

\section{Correspondence to}

Dr Huw Oliphant, oliphanthe@live.com

Accepted 31 August 2014

\section{CrossMark}

To cite: Oliphant $\mathrm{H}_{\text {, }}$ Holmes C, Hassan A, et al. BMJ Case Rep Published online: [please include Day Month Year] doi:10.1136/ bcr-2014-206811

\section{DESCRIPTION}

We present a case of left-sided sudden visual loss in a 75-year-old man with a previous history of uneventful cataract surgery many years prior. During a car journey home, the patient noticed a sudden drop in vision in the left eye, which he noticed readily having poor vision in the fellow eye due to previous retinal detachment. He presented the next morning to the hospital eye service with painless visual loss. There was no history of trauma. Examination demonstrated a visual acuity of counting fingers in the left eye, and a clear inferior subluxation of the posterior chamber intraocular lens and capsular bag (figure 1).

The patient was listed urgently for pars plana vitrectomy under a local anaesthetic, with removal of the lens and capsular bag complex, and insertion of an anterior chamber intraocular lens.

Posterior dislocation of an intraocular lens following cataract surgery can present itself as a very late complication many years down the line, with the incidence being as high as $3 \% .^{1}$ The usual mechanism of dislocation is a gradual weakening of

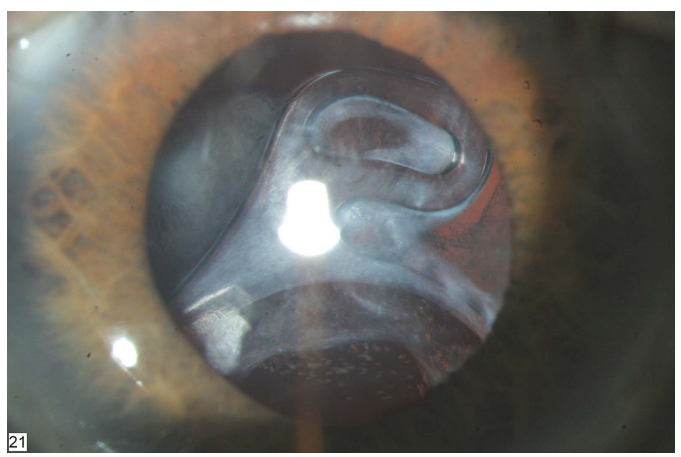

Figure 1 Image of inferior subluxation of intraocular lens and capsular bag. Slit lamp view. the zonular fibres that keep the lens and capsular bag in place. There are frequently predisposing factors with intraocular lens dislocation, including the presence of uveitis, surgical or non-surgical trauma, pseudoexfoliation and, rarely, connective tissue disorders. Management will usually involve either repositioning of the luxated lens, insertion of a sutured posterior chamber intraocular lens or alternatively an anterior chamber lens. The visual prognosis is usually good. ${ }^{2}$

\section{Learning points}

- Intraocular lens dislocation in the vitreous cavity is a recognised cause of sudden visual loss and must be referred on urgently to a specialist.

- It is a sign that can easily be spotted by those in primary care, particularly with the use of a slit lamp.

- Visual prognosis is usually very good.

Acknowledgements Photo taken by Kevin Harrison, medical photographer.

Contributors $\mathrm{HO}$ came up with the idea for the manuscript. $\mathrm{AH}$ and $\mathrm{CH}$ contributed to writing. $\mathrm{CK}$ was the consultant in charge.

Competing interests None.

Patient consent Obtained.

Provenance and peer review Not commissioned; externally peer reviewed.

\section{REFERENCES}

1 Gimbel HV, Condon GP, Kohnen T, et al. Late in-the-bag intraocular lens dislocation: incidence, prevention, and management. J Cataract Refract Surg. 2005;31:2193-204.

2 Kim SS, Smiddy WE, Feuer W, et al. Management of dislocated intraocular lenses. Ophthalmology 2008;115:1699-704.

Copyright 2014 BMJ Publishing Group. All rights reserved. For permission to reuse any of this content visit http://group.bmj.com/group/rights-licensing/permissions.

BMJ Case Report Fellows may re-use this article for personal use and teaching without any further permission.

Become a Fellow of BMJ Case Reports today and you can:

- Submit as many cases as you like

- Enjoy fast sympathetic peer review and rapid publication of accepted articles

- Access all the published articles

- Re-use any of the published material for personal use and teaching without further permission

For information on Institutional Fellowships contact consortiasales@bmjgroup.com

Visit casereports.bmj.com for more articles like this and to become a Fellow 